\title{
Mass Mortality of Porites Corals on Northern Persian Gulf Reefs due to
} Sediment-Microbial Interactions

\author{
Javid Kavousi $^{1 \otimes}$, Parviz Tavakoli-Kolour ${ }^{2}$, Abbas Barkhordari ${ }^{2}$, Arezoo Bahrami ${ }^{2}$ \\ 1. Graduate School of Engineering and Science, University of the Ryukyus, 1 Senbaru, Nishihara 903-0213, Okinawa, Japan \\ 2. Young Researchers Club, Bandar Abbas Branch, Islamic Azad University, PO Box 79159-14 1311, Bandar Abbas, Iran \\ DCorresponding author email: javid.kavousi@yahoo.com \\ International Journal of Marine Science, 2013, Vol.3, No.38 doi: 10.5376/ijms.2013.03.0038
}

Received: 01 May, 2013

Accepted: 03 Jun., 2013

Published: 22 Jul., 2013

Copyright $@ 2013$ Kavousi et al., This is an open access article published under the terms of the Creative Commons Attribution License, which permits unrestricted use, distribution, and reproduction in any medium, provided the original work is properly cited.

Preferred citation for this article:

Kavousi et al., 2013, Mass Mortality of Porites Corals on Northern Persian Gulf Reefs due to Sediment-Microbial Interactions, Indonesia, International Journal of Marine Science, Vol.3, No.38 306-310 (doi: 10.5376/ijms.2013.03.0038)

\begin{abstract}
Little information is available on coral diseases in the Persian Gulf; however, in the recent years, reports of coral diseases increased in particular from Iranian side of the Persian Gulf. In this paper we report a White Mat Disease resulting in mass mortality of Porites colonies at Hormuz Island. This outbreak infected $96 \%$ of all Porites colonies and killed $58 \pm 30 \%$ (mean \pm SD) of all Porites tissues.
\end{abstract}

Keywords Porites mortality; White mat disease; Hormuz Island; Iran

\section{Introduction}

Being among the most diverse ecosystems on the Earth, the world's coral reefs have been threatened by global and local stresses over the last few decades resulting in vast destruction (Burke et al., 2011; Fisher et al., 2011). Disease has been among the most important contributors to the global degradation of coral reefs (Goreau et al., 1998; Weil et al., 2006; Bruno et al., 2007; Rosenberg and Kushmaro, 2011). Little information on the prevalence or types of coral disease, however, exists for the Indian Ocean including the Persian Gulf (Riegl and Purkis, 2012).

The Persian Gulf is known as one of the most extreme environments for coral reefs with high temperature fluctuations from $12^{\circ} \mathrm{C}$ in winter (Sheppard et al., 1992 ) to $38^{\circ} \mathrm{C}$ in summer (Baker et al., 2004), high salinity (up to $39 \mathrm{psu}$ ), high sedimentation rate, low depth (35 $\mathrm{m}$ in average with majority of coral reefs in depth $<10 \mathrm{~m}$ ) and low water circulation especially in the southern part of the Gulf (see Riegl and Purkis, 2012). In spite of being among the most tolerant coral reefs to thermal stress (Burt et al., 2011), coral reefs of the Persian Gulf encounter massive coral bleaching events due to temperature anomalies (Coles and Riegl, 2012; Kavousi et al., unpublished data). Moreover, $85 \%$ of the coral reefs in the Persian Gulf are considered threatened by local stresses (Burke et al.,
2011). Furthermore, coral diseases have been recently reported as another serious threat to the coral reefs of the Persian Gulf.

Although little systematic and quantitative studies have been done in the Persian Gulf (Riegl and Purkis, 2012), in recent years, reports of recognized and uncharacterized coral diseases have increased, especially from the northern Persian Gulf including Larak, Qeshm, and Hengam Islands (Samimi-Namin et al., 2010; Kavousi and Rezai, 2011). In this paper, we report a White Mat Disease resulting in mass Porites mortality from Hormuz Island of the Persian Gulf.

\section{Material and Methods}

During a field survey around some Iranian islands of the Persian Gulf in late August and early September 2012, following a mass coral bleaching, an outbreak of a disease was observed on the reef-building corals of the east of Hormuz Island $\left(27^{\circ} 03^{\prime} \mathrm{N}, 56^{\circ} 30^{\prime} \mathrm{E}\right.$; Figure 1). To estimate the benthic cover of reefs, 10-meter Line Intercept transects were established $(n=9)$ at a depth of $<4 \mathrm{~m}$ where majority of the reefs exist. The number of infected coral colonies was obtained by counting 100 coral colonies randomly. Photoquadrat method $(n=70)$ was used to calculate the coral tissue mortality due to the white mats. Sedimentation rate in the area was obtained by using 


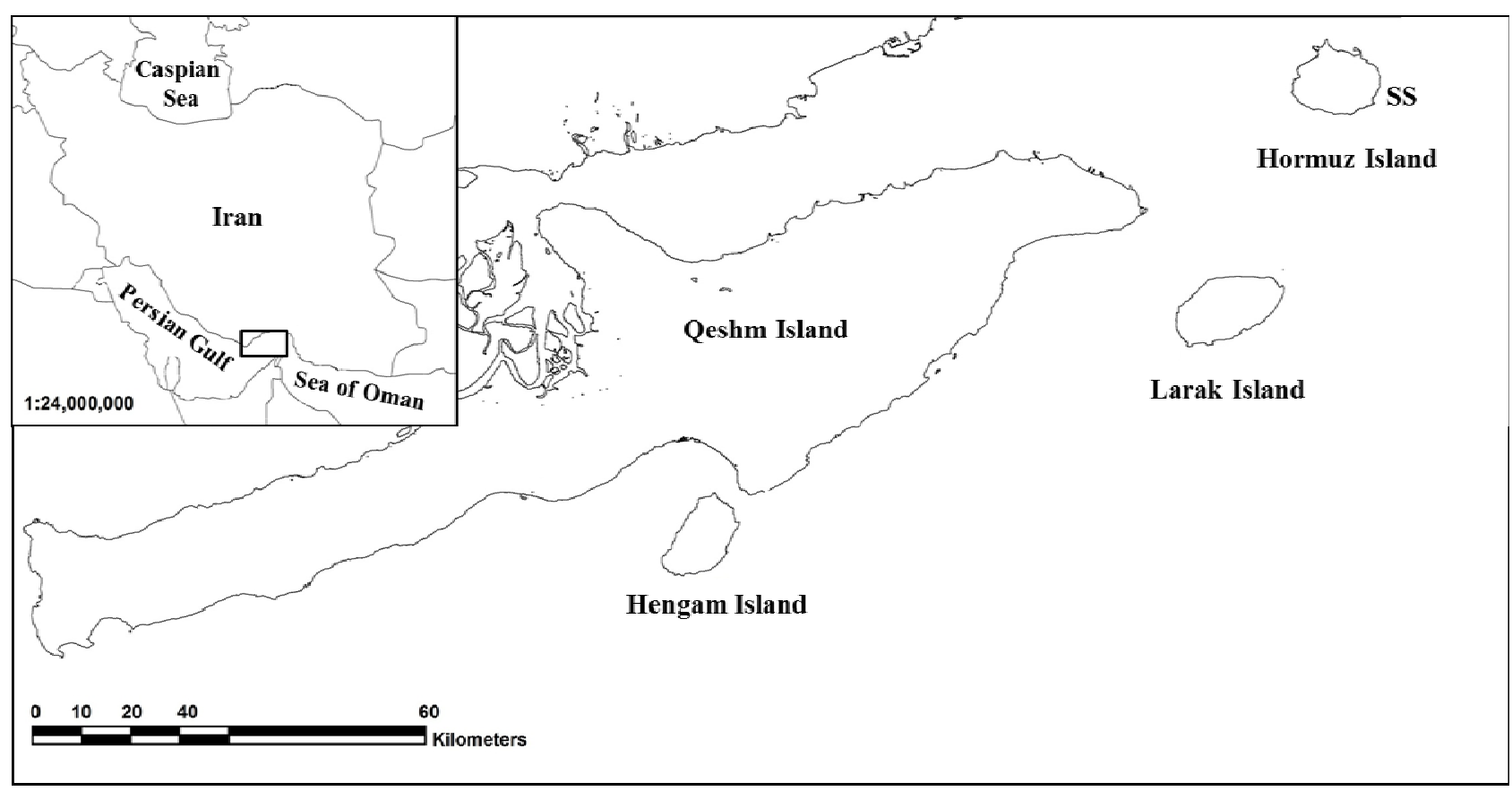

Figure 1 Map of the area including Hormuz Island where was examined in this study. SS= studied site in this study

the accumulated sediments collected with 10-day-sediment traps following the methodology mentioned in Hill and Wilkinson (2004). Three rods with 3 sedimentation traps attached to each rod ( 9 traps in total) were hammered to three sides of the reefs; however, the data presented here are from 6 traps because the other three traps were lost. Sedimentation rate is reported as $\mathrm{gr} / \mathrm{cm}^{2} /$ day.

\section{Results and Discussion}

The main reefs of Hormuz Island, located at the east and 2-4 $\mathrm{m}$ deep, include as main reef-builders zoanthids and scleractinian corals for $59.79 \pm 15.95 \%$ (mean $\pm \mathrm{SD}$ ) and $8.68 \pm 7.01 \%$ (mean $\pm \mathrm{SD}$ ) of substratum, respectively. The predominant coral genus in the area is massive Porites (more than $85 \%$ of the reef-building corals). High sedimentation rate is a permanent characteristic of this site (Figure $2 \mathrm{~A}$ ) and a rate of $0.052 \pm 0.014 \mathrm{gr} / \mathrm{cm}^{2} /$ day was measured. In spite of this high sedimentation, corals and zoanthids have appeared healthy during the last three years (Figure 2B, personal observations); however, in summer 2012, the reef-building corals encountered coral bleaching (Kavousi et al., unpublished data) and outbreak of a disease that followed.

Overgrowth of invasive organisms such as algae (Goreau et al., 1998; Barott et al., 2012) and pathogenic
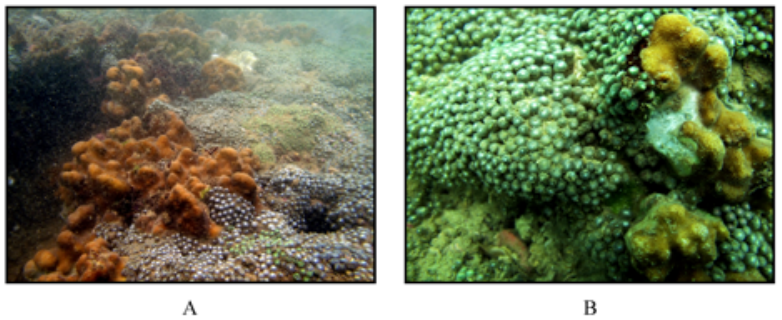

Figure 2 A: Turbid waters due to high sedimentation around coral reefs at eastern Hormuz Island B: Deposition of sediments on live organisms such as corals and zoanthids as a permanent characteristic of this site

bacteria (Kline and Vollmer, 2011) leading to coral mortality is prevalent worldwide but mass coral mortality from sulfate reducing bacteria is a rare phenomenon that was recorded on reef-building Porites corals of Hormuz Island of the Persian Gulf in Summer 2012.

Whereas all coral colonies were affected by thermal stress (from partially bleached to fully-bleached), the Porites corals were overgrown by a white mat of bacteria (Figure $3 \mathrm{~A}$ and B) that infected $96 \%$ of all Porites colonies and killed $58 \pm 30 \%$ (mean \pm SD) of all Porites tissues. The same phenomenon was also observed on several coral genera on the south of Hormuz and Larak Islands. 


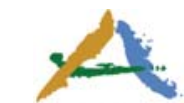

BioPublisher ${ }^{\circ}$

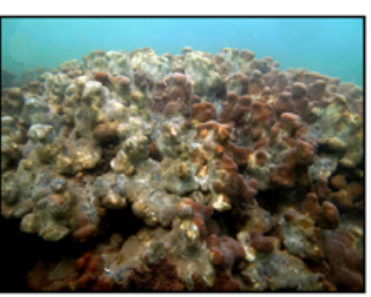

A

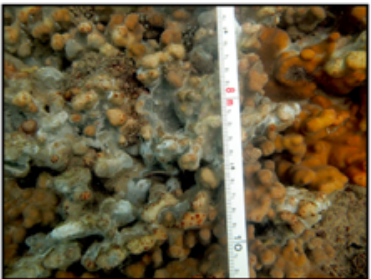

$\mathrm{C}$

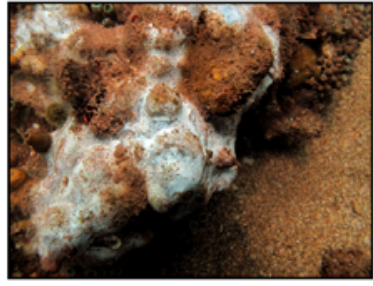

B

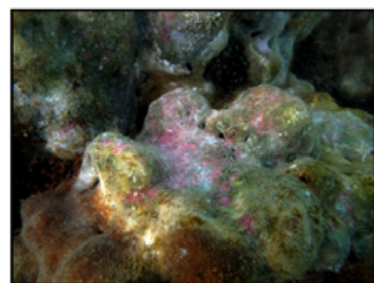

D

Figure 3 A: Mass mortality of Porites colonies at Hormuz Island due to bacterial mats $\mathrm{B}$ : White mat on a Porites colony $\mathrm{C}$ : White mats changed overlying black layers due to iron sulfide precipitation D: Photosynthetic sulfur and non-sulfur bacteria are probably responsible for pink and green colors

Reports on post-bleaching coral mortality due to diseases are increasing worldwide (Bruno et al., 2007; Miller et al., 2009; Riegl et al., 2011; Bastidas et al., 2012). Although, coral reefs facing mild and sometimes severe bleaching can recover quickly (e.g. Goreau et al., 2000; West and Salm, 2003; Riegl et al., 2011), diseases can reduce resilience, coral cover, and reef resistance drastically for several years (Goreau et al., 2000; Rosenberg and Loya, 2004; Sutherland et al., 2004).

Massive Porites corals are known as the most tolerant corals to thermal stress (Goreau et al., 2000; Loya et al., 2001); however, the results of this study indicate Porites corals are still susceptible to the secondary effects of bleaching events including coral diseases. Moreover, reefs affected by coral diseases have less resistance and resilience (Goreau et al., 2000; Rosenberg and Loya, 2004) resulting in more likelihood of being overgrown by invasive organisms and competitors such as macroalgae and other reef builders; however, even under no visible stress, zoanthids are able to overgrow reef-building corals (Figure 4A, B, C; J. Kavousi, personal observation). The reefs to the east of Hormuz Island are now dominated by zoanthids $(59.79 \pm 15.95 \%)$. Whereas reef-building corals were highly affected by the recent bleaching event and its consequences, zoanthids showed no sign of bleaching or sickness. The shift

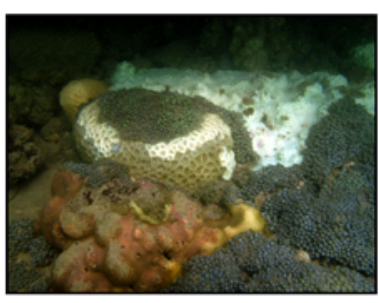

A

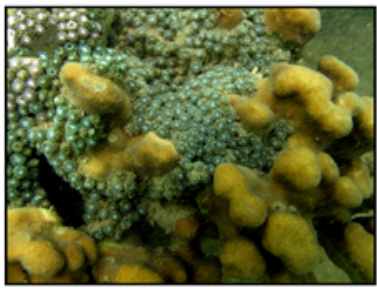

Figure 4 Overgrowth of zoanthids on coral colonies including A: Favia B: Platygyra C: Porites at the east of Hormuz Island

from coral dominated reefs to non-scleractinian coral-dominated reefs due to climate change and its consequences were reported (reviewed by Norström et al., 2009; Bell et al., 2013). This may lead to local extinction of reef-building corals of the east of Hormuz Island under ongoing climate change.

Sulfide oxidizing bacteria such as Beggiatoa, Thiothrix and Thioploca, etc. are suggested to be the dominant bacteria in the white mats (Jorgensen, 1977; Jorgensen and Postgate, 1982; Fenchel et al., 2012). A dark colored underlayer (Figure 3C) that appeared at the white surface of affected tissues less than 24 hours after the first observations is probably due to iron sulfide precipitation. The pink and green colored underlayers observed on the majority of infected coral colonies (Figure 3D) could be photosynthetic sulfur and non-sulfur bacteria; however, microbial examinations are needed.

Although sulfide oxidizing bacteria linked coral mortality was reported (Garrett and Ducklow, 1975; Mitchell and Chet, 1975), previous observations involved very localized coral mortality, often due to artificially induced stress in the laboratory or linked to sediment stress in the field (Weber et al., 2012).

Sulfide oxidizing bacteria are a visible epiphenomenon that is a result, not a cause, of mortality. Coral surface tissue smothered with fine-grained mud creates locally anoxic sites (Erftemeijer et al., 2012) that are colonized by anaerobic, heterotrophic sulfate-reducing bacteria. The Hydrogen Sulfide they produce then 
kills coral tissue (Weber et al., 2006; 2012). The sulfide-oxidizing bacteria live at the interface between the aerated water and the necrotic tissue, and oxidize Hydrogen Sulfide escaping from below with oxygen from above. They precipitate internal elemental sulfur granules (Jorgensen, 1977; Fenchel et al., 2012) that give them a distinctive white mat appearance (Richardson, 1998). The mat tends to trap and maintain anoxic condition (Jorgensen and Postgate, 1982) at the tissue surface (Miller and Richardson, 2012), hastening coral mortality. Thus the disease is a secondary microbial effect of sediment stress (Weber et al., 2012), not a primary pathogen that attacks coral tissue directly. The effects are worst where there is heavy sedimentation, especially coupled to organic loading (Weber et al., 2012), warm conditions, and weak water movement.

The increased number and outbreak of coral diseases reported from the Persian Gulf in the recent years may be evaluated as a sign of future frequent mass mortalities due to coral diseases which could result in reef degradation and coral extinctions. Therefore, it is necessary to monitor long-term effects of coral diseases along with doing histological and microbiological examinations in the Persian Gulf.

\section{Acknowledgement}

We thank Dr. T.J. Goreau for his professional comments to improve the manuscript. English editing was done by T. Goreau and T. McClelland.

\section{References}

Baker A.C., Starger C.J., McClanahan T.R., and Glynn P.W., 2004, Corals' adaptive response to climate change, Nature, 430: 741 http://dx.doi.org/10.1038/430741a

Bell J.J., Davy S.K., Jones T., Taylor M.W., and Webster N.S., 2013, Could some coral reefs become sponge reefs as our climate changes? Global Change Biology, doi: 10.1111/gcb.12212 http://dx.doi.org/10.1111/gcb.12212

Bruno J.F., Selig E.R., Casey K.S., Page C.A., Willis B.L., Harvell C.D., Sweatman H., and Melendy A.M., 2007, Thermal stress and coral cover as drivers of coral disease outbreaks, PLoS Biology, 5: e124 http://dx.doi.org/10.1371/journal.pbio.0050124

Burke L.M., Reytar K., Spalding M., and Perry A., 2011, Reefs at risk revisited, World Resources Institute, Washington DC, USA

Burt J., Al-Harthi S., and Al-Cibahy A., 2011, Long-term impacts of coral bleaching events on the world's warmest reefs, Marine Environmental Research, 72: 225-229 http://dx.doi.org/10.1016/j.marenvres.2011.08.005

Coles S.L., and Riegl, B.M., 2012, Thermal tolerances of reef corals in the Gulf: A review of the potential for increasing coral survival and adaptation to climate change through assisted translocation, Marine pollution bulletin, 72: 323-332Erftemeijer P.L., Riegl B., Hoeksema B.W., Todd P.A., 2012, Environmental impacts of dredging and other sediment disturbances on corals: a review, Marine Pollution Bulletin, 64: $1737-1765$
Fenchel T., Blackburn H., and King G.M., 2012, Bacterial biogeochemistry: The Ecophysiology of Mineral Cycling, Academic Press, pp. 312

Fisher R., Radford B.T., Knowlton N., Brainard R.E., Michaelis F.B., and Caley M.J., 2011, Global mismatch between research effort and conservation needs of tropical coral reefs, Conservation Letters, 4: 64-72 http://dx.doi.org/10.1111/j.1755-263X.2010.00146.x

Garrett P., and Ducklow H.W., 1975, Coral disease in Bermuda, Nature, 253: 349-350 http://dx.doi.org/10.1038/253349a0

Goreau T., McClanahan T., Hayes R., and Strong A., 2000, Conservation of coral reefs after the 1998 global bleaching event, Conservation Biology, 1: $5-15$ http://dx.doi.org/10.1046/j.1523-1739.2000.00011.x

Goreau T.J., Cervino J., Goreau M., Hayes R., Hayes M., Richardson L., Smith G., DeMeyer K., Nagelkerken I., Garzon-Ferrera J., Gil D., Garrison G., Williams E.H., Bunkley-Williams L., Quirolo C., Patterson K., Porter J., and Porter K., 1998, Rapid spread of diseases in Caribbean coral reefs, Revista Biologia Tropical, 46 Supl. 5: 157-171

Hill J., and Wilkinson C., (eds.), 2004, Methods for ecological monitoring of coral reefs, Australian Institute of Marine Science, Townsville

Jorgensen B.B., 1977, Bacterial sulfate reduction within reduced microniches of oxidized marine sediments, Marine Biology, 41: 7-17 http://dx.doi.org/10.1007/BF00390576

Jorgensen B.B., and Postgate J.R., 1982, Ecology of the Bacteria of the Sulphur Cycle with Special Reference to Anoxic-Oxic Interface Environments [and Discussion], Philosophical Transactions of the Royal Society of London B, Biological Sciences, 298, 543-561 http://dx.doi.org/10.1098/rstb.1982.0096

Kavousi J., and Rezai H., 2011, Coral lesions around some Iranian Islands in the Persian Gulf, Galaxea, 13: 5-6 http://dx.doi.org/10.3755/galaxea.13.5

Kline D.I., and Vollmer S.V., 2011, White Band Disease (type I) of endangered Caribbean acroporid corals is caused by pathogenic bacteria, Scientific Reports, 1: 7 http://dx.doi.org/10.1038/srep00007

Loya Y., Sakai K., Yamazato K., Nakano Y., Sambali H., and van Woesik R., 2001, Coral bleaching: the winners and the losers, Ecology Letters, 4: 122-131 http://dx.doi.org/10.1046/j.1461-0248.2001.00203.x

Miller A.W., and Richardson L.L., 2012, Fine structure analysis of black band disease (BBD) infected coral and coral exposed to the BBD toxins microcystin and sulfide, Journal of Invertebrate Pathology, 109: 27-33 http://dx.doi.org/10.1016/j.jip.2011.09.007

Miller J., Muller E., Rogers C., Waara R., Atkinson A., Whelan K.R.T., Patterson M., and Witcher B., 2009, Coral disease following massive bleaching in 2005 causes $60 \%$ decline in coral cover on reefs in the US Virgin Islands, Coral Reefs, 28: 925-937 http://dx.doi.org/10.1007/s00338-009-0531-7

Mitchell R., and Chet I., 1975, Bacterial attack of corals in polluted seawater, Microbial Ecology, 2: 227-233 http://dx.doi.org/10.1007/BF02010442

Norström A.V., Nyström M., Lokrantz J., and Folke C., 2009, Alternative states on coral reefs: beyond coral-macroalgal phase shifts. Marine Ecology Progress Series, 376: 295-306 http://dx.doi.org/10.3354/meps07815

Richardson L.L., 1998, Coral diseases: what is really known?, Trends in Ecology \& Evolution, 13: 438-443 http://dx.doi.org/10.1016/S0169-5347(98)01460-8

Riegl B.M., Purkis S.J., Al-Cibahy A.S., Abdel-Moati M.A., and Hoegh-Guldberg O., 2011, Present limits to heat-adaptability in corals and population-level responses to climate extremes, PloS one, 6: e24802 http://dx.doi.org/10.1371/journal.pone.0024802

Riegl B.M., and Purkis S.J., eds., 2012, Coral Reefs of the Gulf, Springer, pp. 250 http://dx.doi.org/10.1007/978-94-007-3008-3 
Rosenberg E., and Kushmaro A., 2011, Microbial diseases of corals: pathology and ecology, In: Dubinsky Z., Stambler N., (eds.), Coral Reefs: An Ecosystem in Transition, pp. 451-464 http://dx.doi.org/10.1007/978-94-007-0114-4_26

Rosenberg E., and Loya Y., eds., 2004, Coral health and disease, Springer, pp.488 http://dx.doi.org/10.1007/978-3-662-06414-6

Samimi-Namin K., Risk M.J., Hoeksema B.W., Zohari Z., and Rezai H., 2010, Coral mortality and serpulid infestations associated with red tide in the Persian Gulf, Coral Reefs, 29: 509 http://dx.doi.org/10.1007/s00338-010-0601-x

Sheppard C.R.C., Price P., and Roberts C., (eds.), 1992, Marine ecology of the Arabian Region, Academic Press, London, England

Sutherland K.P., Porter J.W., and Torres C., 2004, Disease and immunity in Caribbean and Indo-Pacific zooxanthellae corals. Marine Ecology Progress Series, 266: 273-302

http://dx.doi.org/10.3354/meps266273
Weber M., de Beer D., Lott C., Polerecky L., Kohls K., Abed R.M.M., Ferdelman T.G., and Fabricius K.E., 2012, Mechanisms of damage to corals exposed to sedimentation, PNAS, 109: E1558-E1567 http://dx.doi.org/10.1073/pnas.1100715109

Weber M., Lott C., and Fabricius K.E., 2006, Sedimentation stress in a scleractinian coral exposed to terrestrial and marine sediments with contrasting physical, organic and geochemical properties, Journal of Experimental Marine Biology and Ecology, 336:18-32 http://dx.doi.org/10.1016/j.jembe.2006.04.007

Weil E., Smith G., and Gil-Agudelo D.L., 2006, Status and progress in coral reef disease research, Diseases of Aquatic Organisms, 69: 1-7 http://dx.doi.org/10.3354/dao069001

West J.M., and Salm R.V., 2003, Resistance and resilience to coral bleaching: implications for coral reef conservation and management, Conservation Biology, 17: 956-967 http://dx.doi.org/10.1046/j.1523-1739.2003.02055.x 